日植病報 XXXI，（記念号-2）：266２74（1965)。

\title{
抗生物質とその利 用*
}

\author{
梅 沢 浜夫䊏
}

\section{Hamao Umezawa: Antibiotics and Their Uses}

\section{緒論}

抗生物質の研究は自然界の微生物間の拮抗に際して 作られる抗菌物質を分離し, そのなかから有用物質を 選択するという指導原理に基づいて始められたが，数 多くの抗生物質の化学的研究の結果, 微生物は多種多 様の無数の有機化合物を作ることが明らかになり, 微 生物が作る無数の有機化合物のなかに目的に沿ら物質 を探すといらことが指導原理となつた。かくして，抗 生物質の研究は, 抗菌性の物質から, 抗ウイルスある Wは抗原虫, 抗寄生虫, 抗昆虫作用の物質, 更に制癌 物質の研究に広げられ，将来は微生物生産物中に広く 有用な生物活性物質を探す方向に拡大しょうとしてい る。

抗生物質は発見されると，その生物活性に基づいて その利用的研究が行なわれる。また，応用面を考える 新しい探索法をたて新規な活性を有する抗生物質が見 つけられる。かくして抗生物質の利用は，医薬から農 薬に, また飼料添加剤あるいは食品防腐剤に広げられ ている。またいくつかの抗生物質はその作用機転に基 いて生化学の研究の重要な道具となつている。本文に おいては，抗生物質が利用されている領域と応用面か ら促進されている抗生物質の比較的最近の研究につい て述べることとする。

\section{耐性菌と抗生物诈}

グラム陽性菌, 陰性菌, リケッチァに対する化学療 法はペニシリン,ストレプトマイシン,クロラムフェニ コル, テトラサイクリン類, エリスロマイシンその他 重要抗生物質の発見によつて 1951 年ころ, 殆んぞ完 全に完成したかにみ元たしかし，そののち耐性菌の 出現によつて 1957 年ころ再び新規な化学療法剤が要 求されるようになつた。1941 年ペニシリンの再発見

* 日本植物病理学会 50 周年記念特別講演 1965 年 4 月

** 国立予防衛生研究所, 東京大学応用微生物研究 所, 微生物化学研究所
ののち, 直ちに耐性菌の可能性が警告された。この警 告はペニシリンを含さ培地に細菌を継代培養するとぺ ニシリン抵抗性を獲得するという実験に基づくもので あつたが，このようにして得た病原菌は発病力を失ら ので，その実験的事実と警告の間には大きな矛盾があ つた。実際そののち, 耐性菌はブドウ球菌, 赤痢菌, 大腸菌, 結核菌で問題となつたが, ブドウ球菌, 赤痢 菌, 大腸菌で病人から分離される耐性菌は実験室的に 作つたものと全く違つている。ズルホン剤耐性赤痢 菌が広がつたのは 1950 年であるが，1956 年ころに はズルホン剤のクロラムフェニコル, ストトレプトマイ シンのどれにも耐性の多剂耐性赤瘌菌が現われ，これ ら耐性赤痢菌は耐性因子 R-factor を有し, この Rfactor は接合によつて赤痢菌の間ばかりでなく, 大腸 菌,サルモネラ等の間に伝達され,それらの菌を耐性に することが秋葉・落合・三橋ら 2 の研究によつて明ら かにされた。患者から分離される耐性ブドウ球菌の場 合はこの耐性は三橋らによりファージによつて高頻度 に他のブドウ球菌に運ばれることが確認されよらとし ている。これら耐性菌では, 耐性の機構も実験室の継 代培養で得た耐性菌と異なつている。例光ば病人から 分離されたストレプトマイシン耐性大腸菌は感受性菌 と異なりストレプトマイシンをアセチル化して活性を 失わしめるが，継代培養で実験室的に作つた耐性大腸 菌では，その蛋白合成系，特に ribosomeがストレプ トマイシンに耐性となつている ${ }^{1,2)}$ 。農薬の場合にも, 継代培養で作ると同じ耐性菌が実際に畑で将来問題に なると予測することは安易に過ぎるよらにみえる。

このようにして予測し得なかつた耐性赤㾋菌, 耐性 大腸菌, 酎性ブドウ球菌が現われたが，それは驚くべ き高頻度である。市川・橋等 ${ }^{2)}$ の研究によると 1961 〜 1963 年に病院で分離されたブドウ球菌の 95\% はズ ルホン剂耐性, $47 \%$ はペニシリン耐性, $34 \%$ はスト レプトマイシン耐性， $7 \%$ はクロラムフェニコル耐 性，2３\%はェリスロマイシン耐性である。これら 耐性菌中, テトラサイクリン, ストレプトマイシン, ペニシリン，ズルホン剤に同時に耐性のものは $12 \%$, テトラサイクリン, ペニシリン, ズルホン剂に耐性の 
ものは $12 \%$ である。クロラムフェニコルあるいはェ リスロマイシンに耐性のブドウ球菌はその殆んどすべ てがストレプトマイシン, テトラサイクリン, ペニシ リンズルホン剂に耐性である。

長期の治療を必要とする結核では治療中に, 実験室 の継代培養と同じように耐性菌が出現し，またそれは 新しい患者に感染する。1960 年ころ結核患者の 35\% はストレプトマイシン耐性で, また初めて治療を受け る人の $9 \%$ 既にストレプトマイシン耐性であつた。

このようにして, 耐性ブドウ球菌, 耐性赤痢菌, 耐 性結核菌は新たな有効な抗生物質の研究を要求した。 現在な掞ブドウ球菌，大腸菌あるいは赤痢菌，結核菌 に作用する新抗生物質の研究および新ペニシリンの研 究が続けられているが，その理由は酎性菌のためであ るといらことができる。

1955 年に Kaczka, Hoeksema 等 ${ }^{3}$ によつて見つ けられた Novobiocin はクマロン核を有する抗生物質 であるが，耐性ブドウ球菌に対する作用で評価されて いる。川ロら゙が胙年報告した Coumermycin は構造 的に Novobiocin ${ }^{3)}$ に類似し（図 1 ), Novobiocin と

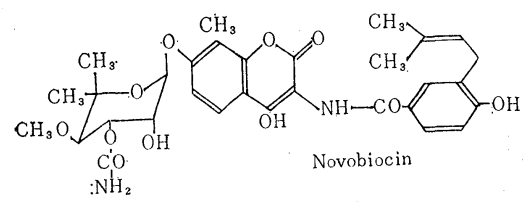

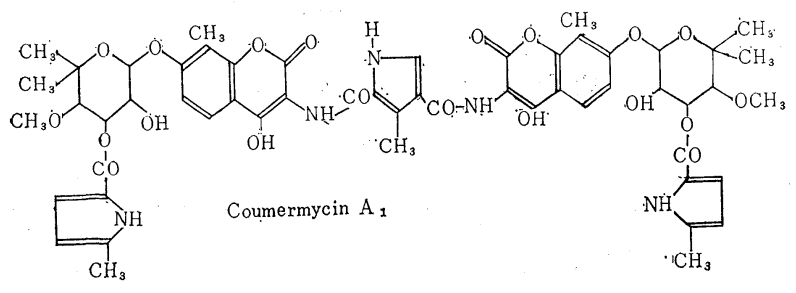

䀯 1

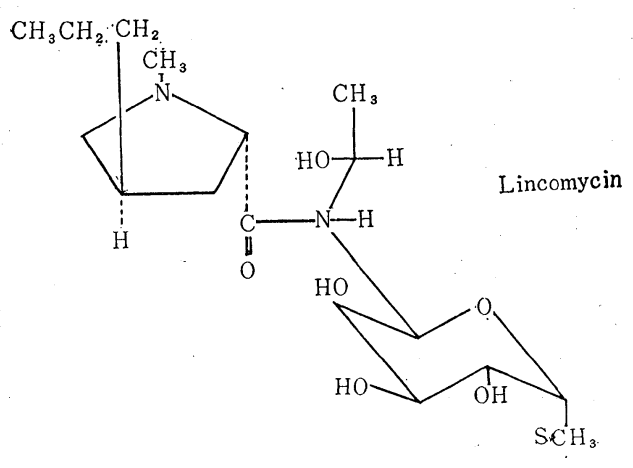

因 2
同様な抗菌スペクトルを示すが，Novobiocin より in vitro では 10倍抗菌作用が強い。1962 年発見され最 近その構造（図 2 $)^{5)}$ が明らかにされた Lincomycin は新規な構造を有する抗生物質で抗菌スペクトル，吸 収排泄, 臨床効果は土リスロマイシン群抗生物質に類 似しているが耐性ブドウ球菌感染症の治療薬として近 く市販されようとしている。Actinospectacin（図３） 1) も耐性ブドウ球菌感染症と大腸菌を目標として研究 されている。

1957 年筆者ら1 はカナマイシンを発見したが，こ の物質は耐性結核菌ばかりでなく，すべての問題とな る耐性菌, すなわち耐性ブドウ球菌, 耐性赤痢菌, 酎 性大腸菌に作用し，耐性菌感染症に対して絶対的必要 性が評価された。ここに抗生物質の研究の例としてカ ナマイシンの研究について述べる。

筆者が新抗生物質の研究に着手したのは 1944 年こ ろであるが，それ以前からカビよりも放線菌にてなれ ていたので放線菌の抗生物質を主として研究すること となつた。そして,水溶性塩基性の物質をいくつか抽出 したが，1948年 Fradiomycinあるいは Neomycin と 現在呼ばれている物質を発見し Streptothricin B と命名しだ”。ころで当時水 溶性塩基性物質は精製が困難で， Fradiomycin 以外は毒性が極めて強いので，そ ののち結核菌に作用する物質のらち，水よ り有機溶剤に溶け精製のより容易な物質の 研究に向つた。1953 年かくして筆者は 3-hydroxypicolinic acid, $\beta$-picoline を含 むPyridomycin を発見した ${ }^{1,8) 。 と こ ろ ~}$ が, Pyridomycin は in vitro でよく結核 菌を阻止したが動物実験では作用しなかつ た。同じころ Amicetin と命名された物質

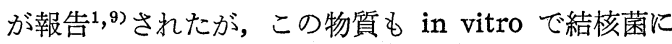
作用したが，in vivo では作用しないようにみ六た。 そのころ, in vitro で結核菌を阻止し，比較的毒性の 少い抗生物質が 20 数種知られていたが, そのうち in vivo で効果を発揮したのは，ストレプトマイシン,ハ イオマイシン拈よび Fradiomycin で, これらはすべ て水溶性塩基性の物質であつた。このよらな理由と, 水溶性塩基性物質の多くは毒性強く, 化学的に精製が 困難であるので，当時多くの研究者がむしろ避けてい たよらにみえたので，笋者らは水溶性塩基性で毒性が 低く結核菌を阻止する物質を，特に詳しく研究するこ ととした。即ち速やかに発育する抗酸性菌 607株を阻 止する培養液のうら, 陽イオン交換樹脂に吸着させて 
溶出する有効物質を選び，それらの物質のらち，マウ スに注射したときマウスが数日後死ぬといら遷延性毒 性のない物質を選ぶこととした。このようにして，カ ナマイシン1), Alboverticillin"1), Phleomycin'1) の 3 種の物質を発見した。これらのらち，カナマイシンは 最も毒性低く，またグラム陽性，陰性菌によく作用す るので, この物質が直ちに詳しく研究された。その結 果, マウスの $\mathrm{LD}_{50}$ は静脈で $320 \mathrm{mg} / \mathrm{kg}$, 皮下で $1,700 \mathrm{mg} / \mathrm{kg}$ ，犬に毎日 $150 \mathrm{mg} / \mathrm{kg}$ 筋注を全量 $10 \mathrm{~g} / \mathrm{kg}$ まで続けても毒性を示さず，猫に対して第 8 神経系に 対してストレプトマイシンより毒性少く, ラットでの 聴神経に対してストレプトマイシンと同程度またはそ れより弱い毒性が観察されたので，臨床研究が行なわ れ, 広くグラム陽性菌, 陰性菌, 結核菌に対する効果 が市川博士等によつて確認された。注射したカナマイ シンは高い血中濃度を示して比較的速やかに尿に排泄 される。カナマイシンの構造は Cron, Lemieux, 梅沢

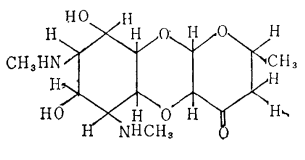

Actinospectacin

図 3

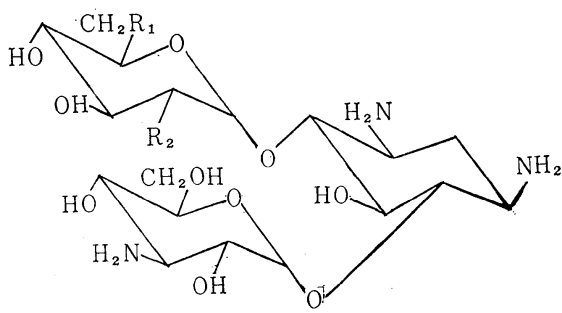

Kanamycin : $\mathrm{R}_{1}=\mathrm{NH}_{2}, \mathrm{R}_{2}=\mathrm{OH}$ Kanamycin $\mathrm{B}: \mathrm{R}_{1}=\mathrm{NH}_{2}, \mathrm{R}_{2}=\mathrm{NH}_{2}$ Kanamycin $\mathrm{C}: \mathrm{R}_{1}=\mathrm{OH}, \mathrm{R}_{2}=\mathrm{NH}_{2}$

図 4

純夫，小川拉よび筆者ら 決定された（図 4 ）。カナマイシン生産菌はカナマイ シンの他にカナマイシン $\mathrm{B}$ 执よび $\mathrm{C}$ を作る。カナマイ シンBはカナマイシンより 5 倍毒性が強く, 製品中に その存在は $2 \%$ 以下におさえられている。カナマイシ ンCは一般にカナマイシンと同じ抗菌力と毒性を示す が，結核菌に対して約 1/10 の作用である。カナマイ シンの誘導体はメタンスルホン酸塩等いろいろ追究さ
れているが, 3-glucosamine の $\mathrm{CH}_{2} \mathrm{OH}$ が $\mathrm{CH}_{3}$ にか えられた deoxykanamycin ${ }^{1)}$ はカナマイシンと同様 な作用と同程度の毒性があると報告されている。1951 年に見つけられたバイオマイシンはその推定構造（図 $5)^{10)}$ が最近報告されたが抗酸性菌を阻止し，抗菌力<smiles>CC(NC(N)=O)C1C=C2N=C(N)N=C(C(=O)NC(COC(=O)CC(N)CCCN)C(=O)NC(CO)C(=O)NC(N)=O)N21</smiles>

図 5 The Structure of Viomycin

はやや弱いが，ストレプトマイシン耐性菌の結核に用 いられていた。最近報告された Capreomycin ${ }^{1)}$ は構 造的には抗菌作用でバイオマイシンに似たペプチッド で, 水解によつて alanine, serine, $\alpha_{1}, \beta$-diaminopropionic acid, $\beta$-lysine, $\boldsymbol{\alpha}$-(2-iminohexahydro-4pyrimidyl) glycineを与え，またもら一つの成分 (Capreomycin III) は $\beta$-lysine を欠く。バイオマイ シンより最近の臨床研究は腎毒性が少いことを示して いる。<smiles>NC1CONC1OCCO</smiles><smiles>NC(=O)CC(N)COC(=O)O</smiles>

四 6

Cycloserine(図 6) は動物実験では結核菌に効果を 示さないが，他の薬剤と併用して人の結核に有効であ ることが確かめられ，耐性結核に使われるようになつ た。この物質は D-alanyl-alanine synthetase を阻 止し, 細菌の細胞壁の合成を阻害する ${ }^{1)}$ 。筆者らは Cycloserine 生産菌の培養汇液から 0-Carbamyl-Dserine（図 6) を分離し ${ }^{1}$ ，この物質が in vitro およ び in vivo で Cycloserine に強い相乗作用を示すこ

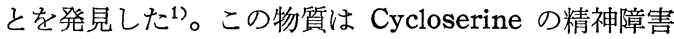
の軽減に役立つか否か現在研究中である。

耐性ブドウ球菌, 耐性赤痢菌, 耐性大腸菌の治療を目 的として新しいペニシリンが 1960 年以来研究されて いる1)。ペニシリンの合成研究の過程で Sheehan 教授 はペニシリンの母核を 6-aminopenicillanic acid と 命名した。またこの物質がペニシリン生産菌株で培養 液中につくられることを 1953 年加藤らが確認した11。 
英国の Beecham 研究所の人たち， Rolinson らはこ の物質を実際に 1959 年抽出した ${ }^{1) 。 ま た, ~ K a u f m a n n ~}$ らはペニシリンGを細菌の酵素で水解して，この物質 を作る方法をみつけだ゚。6-aminopenicillanic acid が得られるようになり，これに諸種の有機酸を結合し て新ペニシリンをつくる研究が発展したが，新ペニシ リンのなかにはペニシリン分解酵素によつて分解され ないペニシリンがあり，それはペニシリン耐性ブドウ 球菌を阻止することが確認された。2,6-dimethoxyphenylpenicillin, 5-methyl-3-phenylisoxazolylpenicillin は耐性ブドウ球菌の感染症に使われる。また

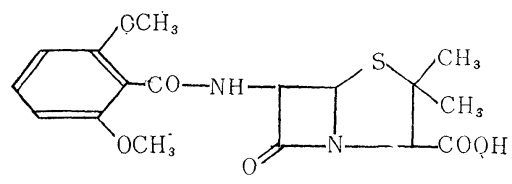

2,6-dimethoxy phenyl penicillin

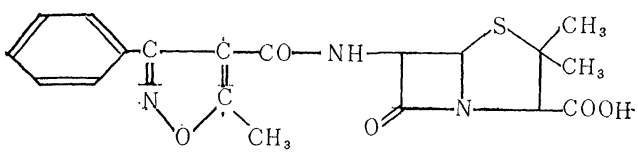

5-Methyl -3-phenylisoxazolylpenicillin

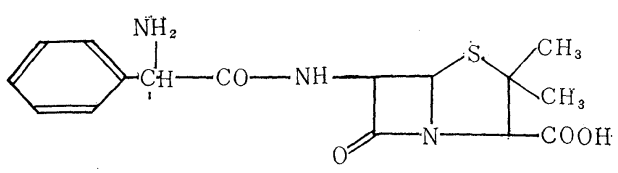

$\alpha$-Aminobenzylpenicillin

図 7
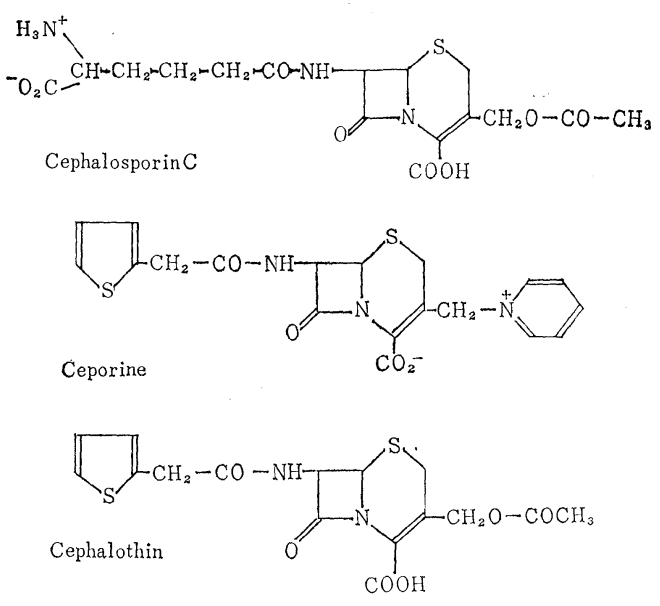

図 8 $\boldsymbol{\alpha}$-aminobenzyl-penicillin は大腸菌等を阻止する（図 7), Cephalosporin (図 8) はペニシリンと同じよう な作用を示し，ペニシリナーゼで分解しない。この母 核 7-aminocephalosporanic acid を化学的に水解し てつくり，それよりいろいろの誘導体が作られたが, Ceporin (Cephaloridine) (図 8 $)^{11)}$, Cephalothin (図 8$)^{1)}$ が耐性ブドウ球菌感染症に対して研究されて いる。

\section{緑膿菌感染症の抗生物算}

耐性菌ほどでないが, 緑膿菌は一般に化学療法剂に 抵抗性が強いので，な打新しい治療楽を要求してい る。1947 年小山・藤正らがみつけた Colistin はペプ チッド抗生物質でグラム陰性菌に作用し, 特に緑膿菌 を阻止するので緑膿菌感染症に用いられるようになつ

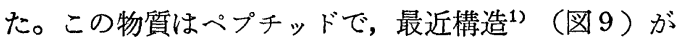
明らかにされたが, Colistin A と Benedict 等が同じ ころみつけた Polymyxin E と同じ物質であると決定

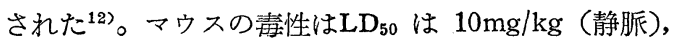
$200 \mathrm{mg} / \mathrm{kg}$ (皮下) で他の医薬用抗生物質よりも毒性は 強いが， $2.5 \mathrm{mg} / \mathrm{kg}$ の注射で $2-3 \mathrm{mcg} / \mathrm{ml}$ 血中に現わ れ, 緑膿菌感染症に効果を発揮している。

\section{Colistin A}

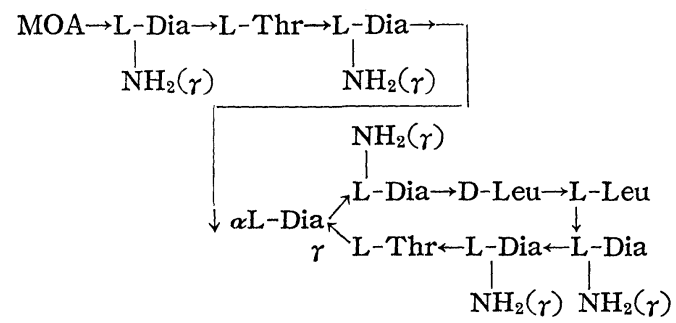

MOA : 6-methyloctanoic acid

Dia : L- $\alpha, \gamma$-diaminobutyric acid

$$
\text { 図 } 9
$$

のちに述べる Kasugamycin は筆者らがイネいもち 病に作用する物質として発見したが ${ }^{13)}$ ，極めて毒性が 少いので医薬用の利用を追究し, 緑膿菌感染症に有効 であろらと推定した ${ }^{14,15)}$ 。病人から分離した 32 株の 緑膿菌は $0.5 \%$ ペプトン水中でその 12 株は $50 \mathrm{mcg} / \mathrm{ml}$ で, 19 株は $25 \mathrm{mcg} / \mathrm{ml}$ で, 1 株は $12.5 \mathrm{mcg} / \mathrm{ml}$ で阻 止され，この阻止作用は血清添加で弱められない。マ ウスに $1 \sim 100$ M. L. D (致死量) の緑膿菌を感染させ たとき, $100 \mathrm{mg} / \mathrm{kg}$ でその感染を阻止した。100mg/kg 鬼の皮下に注射したとき， $100 \mathrm{mcg} / \mathrm{ml}$ 血中に現われ， 約 8 時間で尿中にすべて排泄された。かくして, 臨床 
研究が行なわれたが，尿路感染症に効果を発揮するこ とを市川博士らは観察している。Kasugamycin の臨 床的応用はこの物質を他の目的で抽出したのち，その 医薬的応用を考えて発展したものである。

\section{医薬用抗力ビ抗生物诈}

抗菌性の抗生物質が研究されると, 抗カビ抗生物質 が研究されるのは当然であり，分離された抗カビ物質 について医薬用の用途を研究するのは当然である。敗 血症や肺などを犯す Candida による病気はまれであ るが，完全な治療薬を要求している。放線菌は数多く の polyene 抗カビ物質をつくり, Nystatin (tetraene), Pimaricin (tetraene), Pentamycin (pentaene), Trichomycin (heptaene), Amphotericin B (heptaene）は局所的に使われている1。なお pentaene ある いは heptaene 抗カビ物質は原虫である Trichomonas の感染阻止にも使われる。1939 年 ${ }^{16)}$ カビの培養によ つて得られた Griseofulvin (図10) ${ }^{1)}$ は初め農薬用の<smiles>COc1cc(O)c2c(c1Cl)OC1(C(=O)C2C)C(C)CC(=O)CC1C</smiles>

図 10

用途が考えられたが，1958 年に至つて，それを経口 的に与えたとき皮膚の角質に分布し，みずむしのカビ を阻止するのでみずむしの特効薬となつた。この物質 はカビの Chitin 合成を阻害する1)。住木らが Paecilo- myces varioti からみつけた Variotin (図11) て毒性の低い物質であるが，みずむしの病原菌に局所 的に作用する。抗カビ作用のある抗生物質は数多く見 つけられているが，その大部分は毒性が強く医薬とな るものが殆んどないのは抗細菌物質と比較して注意す べきことである。

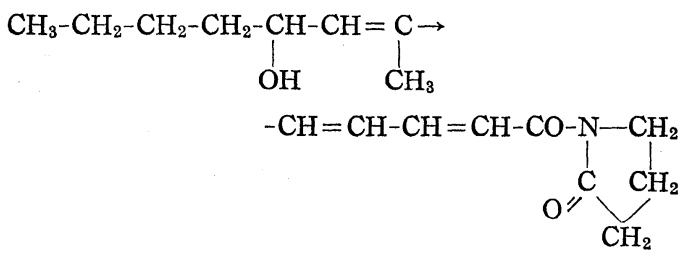

Variotin

図 11

\section{抗ウイルス物诈の研究}

抗ウイルス抗生物質の研究が応用を目的として起る のは当然である。しかし，有用な物質は未だ見つかつ ていない。ただ, 筆者等がみつけて構造を決定した Amidinomycin (図12) ${ }^{1)}$ は石田らの Myxoviromycin と同じであるがインフルエンザ・ウイルスの発育を阻 止する。抗ウイルス作用が報告された Noformicin (図12) ${ }^{1)}$ またウイルスに作用することが知られている Netropsin (図12) \& Amidinomycin と同じように $\beta$-ethylamidine を含んでいることは興味深い。

抗ウイルス抗生物質のうちで，最もはつきりと治 療効果を示したのは猿の実験で小児麻痺に効果を示し た Statolon ${ }^{1)}$ と Helenine ${ }^{1)}$ である。 Statolon は Penicillium stoloniferum がつくる高分子の polysac-<smiles>CCOC(=O)NCCC(=N)N</smiles><smiles>N=C(N)CCNC(=O)C1CCC(=N)N1</smiles><smiles>Cn1cc(NC(=O)NCC(=O)NCCC(=N)N)cc1C(=O)NCCCNC(=N)N</smiles> 
charide で, Helenine は Penicillium funiculosum が つくる極めて不安定な Nucleoprotein である。

抗ウイルス物質の研究は 1950 年ころ活発に行なわ れたが，人のウイルス病では病気が発見されたとき， 既にウイルスの量は最高に達しているのでその後の抗 ウイルス物質の投与が効果を発揮するか否かについて 多くの疑問がもたれ，また容易に毒性のない抗ウイル ス物質は見つけられないのでその研究は 1950 年ごろ 下火になつた。しかし最近ウイルスと癌の問題も加え てこの研究には再び力が入れられている。その中には RNA ファージ阻止物質を見つけて人のウイルス病に 適用しょらとする試みもある。最近諸種のカビから得 られる Tenuazonic acid (図13) ${ }^{1)}$ に抗ウイルス作用 と制癌作用があることが報告されている。<smiles>C=CC(C)C1N=C(O)C(C(C)=O)=C1O</smiles>

Tenuazonic acid

\section{制癌抗生物犋の研究}

1950 年ころ筆者は抗ウイルス物質の研究をしてい たが，ウイルスの増加を特異的に阻止する物質はない が動物細胞を阻止する物質は多数存在することをみた ので，その中には選択的に癌細胞を阻止する物質はな いかと考えて制癌物質を研究し，1953年 Sarkomycin を報告 ${ }^{17)}$ したが，そののち制癌抗生物質は現在におい ても, 最も重要な 抗生物質の研究領域である。しか し，未だ信頼できる癌の薬は見つけられていない。そ の理由はこれまで臨床に試みられた作用の強い物質の すべてが強い慢性の毒性を人に示すからである。 Mitomycin C を 5 10mg/ $\mathrm{kg}$ 腹腔注射すると半数の マウスは 5 10 日後死亡するが, $1.25 \mathrm{mg} / \mathrm{kg}$ を毎日 注射するとその総量が 1 回注射の総量になつてから 5 〜10日で死亡する。Actinomycin でも 1 回に 0.8mg / kg 注射すると 2 日間で死亡するが，これを 30 日間 毎日注射したときの致死量は $0.8 \mathrm{mg} / 30 \mathrm{~kg} /$ 日である。 即ち 1 回の注射で毒性が少く見兊ても, 極めて強い 慢性毒性を有している。更に制癌物質は通常マウスよ

り犬に約 10 倍毒性が強く,人にも犬と同じょうに毒 性が強い上らに見觉る。かくして現在安全に有効量を 人に毎日注射できる癌の薬は抗生物質の中にも合成さ れる化合物の中にもみつけられていない。

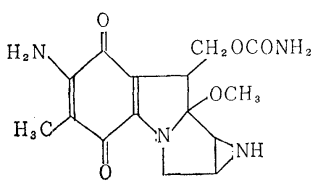

mitomycin C

図 14

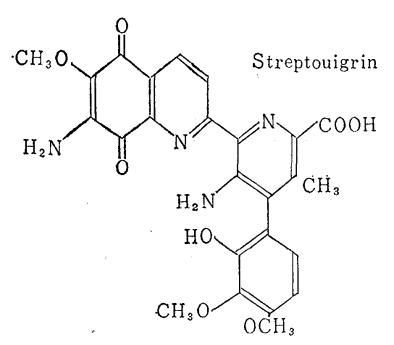

図 15

これまで見出された制癌抗生物質はその制癌作用よ り, その作用機転に基いて生化学の研究の道具とし てより役だつている。Mitomycin C (図14) は細胞の 中で活性化され ${ }^{18)}$, DNA の合成を阻害する。筆者が みつけた銅を含む抗生物質 Phleomycin は DNA polymerase を特異的に阻害する1)。 Streptonigrin （図15）も DNA の合成を阻害するという²。Actinomycin は DNA による RNA 合成を阻害し1), Chromomycin も類似の作用が考慮されている1。 Pluramycin \& m-RNA の合成を阻害することが考 慮されている。最近石田らは分子量 9,000 の酸性のポ リペプチッドに強い制癌作用を認めて Neocarzinostatin と命名して報告したが，この物質は Sarcina lutea の DNA の合成を阻害し, Mitomycin と同じ ように既成 DNA を破壊する。

ア ミノ酸分析で Asp (11), Thr (5), Ser (8), Glu (4), Pro (6), Gly (4), Ala (14), Val (3), Met (2), L-leu (5), Leu (4), Tyr (3), Ly (8), His (5), Arg (5), $\mathrm{NH}_{3}$ (11) を与えるポリペプチッドで ある。Enomycin は筆者等によつてみつけられェーリ ッ癌細胞, HeLa 細胞, マウス肝細胞の Cell-free 系で蛋白合成を阻害する。この物質は $E$. coli の蛋白 合成は阻害しない。 Raromycin もエーリッヒ癌細胞 
の蛋白合成系を阻害する。

制癌抗生物質は実験動物腫瘍と癌細胞の組織培養を 主とした材料として研究されているが，補助的な方法 として，変異原性の活性によつて，あるいは Phage の inductionを起す作用に基いて探されてもいる。制 癌抗生物質の研究は最も重要な領域ではあるが，その ためにはより探索法の進歩が必要である。従来の制癌 抗生物質はその作用機転に基いて生化学上の重要な道 具となつているが，これから新しい探索法を設立する ために役だつかも知れない。

\section{飼料添加郕および食品保存用抗生物犋 ${ }^{19,20,21)}$}

医薬用抗生物質以外に 1949 年ころから最も早く発 展したのは鷄, 豚等の発育促進のための飼料添加剤で ある。グラム陽性，陰性菌を共に阻止する，あるいは グラム陽性菌を阻止する抗生物質で毒性の少い物質は 腸内細菌に発育のため好影響を与えるようにみえる が，それらは例えばペニシリン,テトラサイクリン類， Bacitracin, Tylosin, Mikamycin ${ }^{1)}$ のように飼料添 加剤として動物の発育を促進する。豚の原虫を阻止す るので動物治療薬に導入された Hygromycin $\mathrm{B}^{11}$ も最 近は主として飼料添加郕として用いられている。

抗菌作用を有する無毒な抗生物質には食品保存剤とし ての用途が考慮される。なお，この場合，耐性菌の誘 発を考慮して, 料理されて飲食するときは分解してい ることが好ましいとされている。この目的に，魚，肉 類の保存に Chlortetracycline, Oxytetracycline が, また缶詰で減菌しがたい菌の阻止，あるいはチーズの 雑菌の発育阻止飞乳酸菌がつくる $\mathrm{Nisin}^{22}$ が用いられ ている。Mcrolide 抗生物質の一つ, Tylosin ${ }^{11}$ は缶詰 食品の殺菌に対してその用途が追究されている。

\section{農薬用抗生物诈}

医薬用に発展した抗生物質に農薬用の用途を考慮す るのは当然であり，例穴ばストレプトマイシンが農薬 としての用途を有することは上く知られている。ある いは抗カビ抗生物質の研究で得た Cycloheximide に も農薬用の用途が確立している。医薬用の抗生物質に 農薬上の利用を考兄て出発した農薬用抗生物質の研究 は次に新抗生物質について農薬としての用途について 研究するようになつた。例壳ば，筆者の Phleomycin は抗菌作用に基いて発見された物質であるが，Pridham, Mitchel 等は米国のインゲン, コムギのさび病 に作用することを観察した。更に Blasticidin $\mathrm{S}^{11}$ の報 告後, 日本でイネいもち病拈よび白葉枯病に有効な抗
生物質を目的とする新抗生物質の研究が盛んに行なわ れている。

いもち病に作用する抗生物質を探す方法として, 従 来は Piricularia oryzae を阻止した培養液についてポ ット試験を行ない, ポット試験で有効な培養沪液から 有效物質の抽出が試みられた。またいもら病菌の抗菌 試験法として pH7.0 の見里培地が用いられた。しか し Kasugamycin の研究はこの方法では見落される有 効物質が存在することを示している。

M-338 と番号を付した培養汇液はポット試験でい もち病に治療的効果を発揮したが， $\mathrm{pH} 7.0$ の見里培 地上でいもち菌を阻止しなかつた。有効物質はブタ， ールに抽出されず, 水溶性のように思われた。ポット 試験では有効で, 抗菌作用が認められない可能性とし て，有効物質がイネの葉の中で活性化されること，あ るいはイネの葉の中と同じ条件を与劣ればいもち菌発 育阻止作用を示すことが考兄られ，更にイネの抵抗性 を高める可能性も考兄られた。まず最初の二つの可能 性を調べるために, イネのホモグネートを培養沪液に 作用させてみた。しかし，この処理で抗菌作用は見里 培地上に現われなからた。次にイネを漫出した稲汁培 地を作り $\mathrm{pH} 3$ から $\mathrm{pH} 9$ 亿調整した。すると $\mathrm{pH} 5.5$ 以下の培地で明らかに抗菌作用を示した。その後, イ ネの研究者によればイネの $\mathrm{pH}$ は 5.0 付近であると いら。純䊉に Kasugamycin を得たのち, 稲汁培地の 希釈法で，いるち病菌に対する阻止作用を調べると， $\mathrm{pH} 5.0$ では $0.76 \mathrm{mcg} / \mathrm{ml}$ で阻止するのに, $\mathrm{pH} 7.0$ で は $100 \mathrm{mcg} / \mathrm{ml}$ でも明膫な阻止作用を示さなかつた。 このことはいもち病の in vitro のスクリーニングでは 培地の $\mathrm{pH}$ を 5 5.5 とすべきであることを示してい る。このようにしてカップ法でも有効物質を定量する ことができるようになり，この培養液中の有効物質は 陽イオン交換樹脂の吸着および活性炭クロマトグラフ ィーで速かに精製された。精製された Kasugamycin について石山は繰返し試験し, それが培養液中の真の 有効成分であることを確認するに至つた（日本抗生物 質学術協議会研究会, 1964 年 11 月発表)。

カスガマイシンは水解すると d-inositol を与光, また 2,3,4,6-tetradeoxy-2,4-diamino-D-mannose である Kasugamine を与克, 更に反応途中で, Kasugamine のC-4 のアミノ基にシュウ酸が結合した Kasugamycinic acid を与光，なた残る C, N は Acetolysis で N-acetylformamide を与える。甘味を有 し， 1 種のアミノ酸糖体抗生物質である。いもち菌を 強く阻止するが，他の細菌には既に述べた緑膿菌以外 
強い抗菌作用を示さない。いもち病菌の場合と異な り, 塩基性の抗生物質として, 緑膿菌, Pseudomonas fluorescens などの細菌には $\mathrm{pH} 7$ あるいは弱アルカリ 性で強い抗菌作用を発揮する。

イネいもち菌の感染を強く防止することと, 毒性が 低いことはこの物質の顕著な特徴である。マウス, ラ ット, 鬼すべて $\mathrm{LD}_{50}$ は $1 \mathrm{~g} / \mathrm{kg}$ 以上で, 猿に $800 \mathrm{mg}$ $/ \mathrm{kg}$ 数回注射しても肝, 腎, 造血臟器の機能を障害せ ず, 犬に 300 400 mg/kg の筋内注射を 50 日続けて

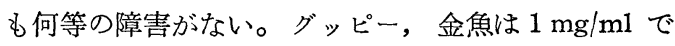
も死亡しない。 $1 \mathrm{mg} / \mathrm{ml}$ を眼に点滴しても刺激しな い。人に既に 1 日 $3 \mathrm{~g}$ 注射あるいは内服が行なわれて いるが何等副作用がない。植物に対しても $100 \mathrm{mcg} / \mathrm{ml}$ の散布はどの植物にも薬害がなく, $10 \mathrm{mcg} / \mathrm{m} 1$ 以上で いるち病に治療的効果を発揮する。大腸菌を用いた実 験では，その蛋白合成系を阻害する。

Blasticidin S と比較して Kasugamycin は人, 家 苗, 魚,植物に薬害がなく,従つて必要とすれば高濃度 を用いて強い効果を発揮させることができる。新しい 物質が得られるごとにとれは古い物質より利点があつ て利用されなければならない。殊に農薬において，そ の穀物を食べる人に対する毒性ばかりでなく，これを 使う人たちへの毒性で心配ないものを使らょうにしな ければならない。

イネ白葉枯病もいもち病についで重要な研究対象と されている。B.C.G. 菌を阻止し, 組織培養で HeLa 細胞を強く阻止した鈴木らが見つけた Cellocidin, 即 ち actylene dicarboxamide は $200 \mathrm{mcg} / \mathrm{ml}$ で白葉枯 病に効果を示した。筆者は吉田肉腫細胞を組織培養で 阻止する物質を探して Formycin と命名した物質を 分離した ${ }^{23)}{ }_{0} \mathrm{C}_{10} \mathrm{H}_{13} \mathrm{~N}_{5} \mathrm{O}_{4} \cdot \mathrm{H}_{2} \mathrm{O}$ の分子式を有し, 141〜 $142^{\circ} \mathrm{C}$ で融解し $252^{\circ} \mathrm{C}$ で分解し, 酸性の PK 9.7 と 塩基性の $\mathrm{PK} 4.4$ を示し, 紫外部吸収で $0.1 \mathrm{~N} \mathrm{HCl}$ 中 で $234 \mathrm{~m} \mu\left(\mathrm{E}_{1 \mathrm{~cm}}^{1 \%} 280\right), 295 \mathrm{~m} \mu\left(\mathrm{E}_{1 \mathrm{~cm}}^{1 \%} 340\right)$ に $0.1 \mathrm{~N}$ $\mathrm{NaOH}$ 中で $235 \mathrm{~m} \mu\left(\mathrm{E}_{1 \mathrm{~cm}}^{1 \%} 500\right), 305 \mathrm{~m} \mu\left(\mathrm{E}_{1 \mathrm{~cm}}^{1 \%} 260\right)$ 拈よび $\mathrm{H}_{2} \mathrm{O}$ 中で $295 \mathrm{~m} \mu\left(\mathrm{E}_{1 \mathrm{~cm}}^{1 \%} 390\right)$ に最大吸収を 示した。Eosine-Mercury 反応は陽性でプリン類似の 構造が推定され，その作用は代謝拮抗物質と又られ た。イネ白葉枯病菌 ( $X$. oryzae ) を比較的強く阻止し たので, この物質は石山らにより白葉枯病に対する試 験が行なわれた。その結果その $1.56 〜 3.2 \mathrm{mcg} / \mathrm{ml}$ は Cellocidin の $200 \mathrm{mcg} / \mathrm{ml}$ と同等の効果を示した。次 に Formycin の化学的研究の途中に沶いて, 第二の 物質 Formycin B が同じ菌の培養液中に存在するこ
とが確認され，それは抽出精製された。Formycin B は $\mathrm{C}_{10} \mathrm{H}_{12} \mathrm{~N}_{4} \mathrm{O}_{5}$ の分子式を有し, $247^{\circ} \mathrm{C}$ で分解し, $[\boldsymbol{\alpha}]_{\mathrm{D}}^{20}$ は $-51.5^{\circ}\left(\mathrm{C} 1, \mathrm{H}_{2} \mathrm{O}\right), 0.1 \mathrm{~N} \mathrm{HCl}$ 中で 221 $\mathrm{m} \mu\left(\mathrm{E}_{1 \mathrm{~cm}}^{1 \%} 543\right), 276 \mathrm{~m} \mu\left(\mathrm{E}_{1 \mathrm{~cm}}^{1 \%} 300\right), 0.1 \mathrm{~N} \mathrm{NaOH}$ 中 で $230 \mathrm{~m} \mu\left(\mathrm{E}_{1 \mathrm{~cm}}^{1 \%} 643\right), 292 \mathrm{~m} \mu\left(\mathrm{E}_{1 \mathrm{~cm}}^{1 \%} 338\right)$, 水中 で $219 \mathrm{~m} \mu\left(\mathrm{E}_{1 \mathrm{~cm}}^{1 \%} 348\right), 280 \mathrm{~m} \mu\left(\mathrm{E}_{1 \mathrm{~cm}}^{1 \%} 294\right)$ 飞最大 吸収を示す。この物質は米原・鈴木等が別の放線菌の培 養液から Formycinを抽出し，同時に得た物質Laursin としても報告された。Formycin からFormycin B は 筆者扣よび米原らによつてみられたように脱アミノ反 応で化学的にまたは酵素反応で变換される。特に筆者 らがみたように Aspergillus から得られるアデノシン 脱アミノ酵素で Formycin は Formycin B にか兄ら れる。Formycin の $X$. oryzae 以外の抗菌力は一般 飞弱いが，Ps. decumbae を $12.5 \mathrm{mcg} / \mathrm{ml}$ （B は 50 $\mathrm{mcg} / \mathrm{ml})$, Piricularia oryzae を $3.12 \sim 25 \mathrm{mcg} / \mathrm{ml}$ (Bは $>100 \mathrm{mcg} / \mathrm{ml})$, Pellicularia filamentosa を 6.25 $\mathrm{mcg} / \mathrm{ml}$ (B は $50 \mathrm{mcg} / \mathrm{ml}$ ) で, Xanthomonas oryzae を $0.78 \mathrm{mcg} / \mathrm{ml}$ (Bは $2.12 \mathrm{mcg} / \mathrm{ml}$ ) で阻止しまた Formycin は Mycobacterium 607 Kirchner 培地中 で阻止したが，Bには作用がみられなかつた。一般に Formycin の方がBより抗菌作用は強い上うにみ兄る が, マウスの $\mathrm{LD}_{50}$ は Formycin は 250 500 mg $/ \mathrm{kg}$, B は $1000 \mathrm{mg} / \mathrm{kg}$ で, B が毒性低く, HeLa 細 胞を Formycin は $1.52 \mathrm{mcg} / \mathrm{ml}$ で变性を起すが B は $1280 \mathrm{mcg} / \mathrm{ml}$ で漸く変性を起し, 吉田肉腫細胞を Formycin は $0.5 \mathrm{mcg} / \mathrm{ml}$ で $71 \%$ 阻止したのに Bは $20 \mathrm{mcg} / \mathrm{ml}$ で阻止作用を示さなかつた。Formycin も Formycin B (Laursin) \& $5 \mathrm{mcg} / \mathrm{ml}$ 付近でストレプ トマイシン $500 \mathrm{mcg} / \mathrm{ml}$ に相当する防除効果をイネ⿱㇒日勺 葉枯病に示し, 白葉枯病には注ぼ同じ程度の作用であ る。両者共に $10 \mathrm{mcg} / \mathrm{ml}$ で僅かな薬害が, $20 \mathrm{mcg} / \mathrm{ml}$ で明膫な薬害を示す。かくして Formycin および Formycin B (Laursin) は直場試験の価值ありと判 断されるに至つた（Formycin B，Laursin は 1965 年 3 月, 日本抗生物質学術協議会に発表された)。

Blasticidin S 以来わが国で農業用の 抗生物質 の研 究が盛んに行なわれるようになり，今後ますますそ れはわが国の抗生物質の研究の特徵とならうとしてい る。この場合にも従来のスクリーニング法をそのまま に適用するばかりでなく念入りにそれぞれの植物病の 病理に基いてスクリーニング法を組立てるのが成功へ の近道であると思われる。 
総括

従来, 抗生物質は抗菌作用および抗細胞作用に基い てその用途が開発されてきたが，最近 Monorden ${ }^{11}$ と いら抗生物質に鎮静作用があることが観察され，更に Ferrimycin ${ }^{1)}$ という抗生物質に拮抗する Ferrioxamine1) そついてはそれが $\mathrm{Fe}^{+++}$とキレートして毒性が 少いので過剩の体中の $\mathrm{Fe}^{+++}$を除き，血液病に用い られている。既に報告されている抗生物質について も, その化学的研究と作用機転の研究が行なわれる と，それから新しい種類の用途が発展するかも知れな い。抗生物質の研究はその利用面と密接に結びついて 発展して来たものである。抗菌性に基く利用面によつ て既に多くの発展を遂げた。病理的，生化学的の研究 で，ある生体反応の阻止をする物質が利用される可能 性が確立されれば，それに基づいて更に新しい生物活 性を有する微生物生産物の領域に発展するわけであ る。

\section{交献}

1. Umezawa, H. (1964). Recent Advances in Chemistry and Biochemistry of Antibiotics. Microbial Chemistry Research Foundation, 403 Kami-Osaki, Shinagawa-Ku, Tokyo, Japan （本書に交献の記されているものは本書を本交で 引用した。本書の索引から各交献をひかれたい。)

2. 第 10 回日本化学療法学会関東及び第 12 回日本 伝染病学会関東，東日本シムポジウム（1964）。 J. Antibiotics, B, $17: 109$.

3. Kaczka, E.A., Wolf, F. J., Ruthe, F.P., and Folkers, K. (1955). J.A.C.S., $77: 6404$.

4. Kawaguchi, H., Naito, T., and Tsukiura, H. (1965). J. Antibiotics, $184: 11$.

5. Hoeksema, H., Bannister, B., Birkenmeyer, R.D., Kugan, F., Magerlein, B. J., MacKellar, F. A., Schroeder, W., Slomp, G., and Herr, R. R. (1964). J.A.C.S., 86 : 4223

6. Argoudelis, A.D., Fox, J.A., Mason, D. J., and Eble, T.E. (1964). J.A.C.S., 86 : 5044.

7. Umezawa, H., Hayano, S., and Ogata, Y. (1948). Jap. Med. J., $1: 504$.

8. Maeda, K., Kosaka, H., Okami, Y., and Umezawa, H. (1953). J. Antibiotics, 6A : 140.

9. Flynn, E.H., Hinman, E.L., Caron, E.L. and Wolf, D. O. (1953). J.A.C.S., 75 : 5867.

10. Bowie, J.H., Cox, D.A., Johnson, A.W., and Thomas, G. (1964). Tetrahedron Lett., 3305; Dyer, J.R., Kellogg, C.K., Nasser R. F. and Stre etman W.E. (1965). Tetrahedron Lett., No. $10: 585$.

11. Stewart, G. T. (1964). Lancet No. 7373 : 1305.

12. Wilkinson, S., and Lowe, L.A. (1964). J.A.C.S., 4107.

13. Umezawa, H., Okami, Y., Hashimoto, T., Suhara, Y., Hamada, M., and Takeuchi, T. (1965). J. Antibiotics 18 A: 101.

14. Hamada, M., Hashimoto, T., Takahashi, T., Yokoyama, S., Miyake, M., Takeuchi, T., Okami, Y., and Umezawa, H. (1965). J. Antibiotics $18 \mathrm{~A}: 104$.

15. Takeuchi, T., Ishizuka, M., Takayama, H., Kureha, K., Hamada, M., and Umezawa, H. (1965). J. Antibiotics 18 A: 107.

16. Oxford, A.E. (1939). Biochem. J. $33: 240$.

17. Umezawa, H., Takeuchi, T., and Nitta, K. (1953). J. Antiobiotics 6A : 100, 6A : 147.

18. Szybalski, W. and Iyer, V.N. (1964). Federation Proceedings, $23: 946$.

19. First International Conference on Antibiotics in Agriculture, Publication 397. (1956). National Academy of Sciences-National Research Council, Washington, D. C.

20. Goldberg, H.S. (1959). Antibiotics, Their Chemistry and Non-Medical Uses. D. Van Nostrand Company, Inc. Princeton, N. J.

21. Woodbine, M. (1962). Antibiotics in Agriculture, Butterworths, London.

22. Berridge, N.G., Newton, G.G.F., and Abraham, E.P. (1952). Biochem. J., $52: 529$. Newton, G. G. F., and Abraham, E. P. (1953). Nature, 171 : 603., Cheeseman, G., and Berridge, N. (1959). Biochem. J., 71: 815.

23. Hori, M., Ito, E., Takita, T., Koyama: G., Takeuchi, T., and Umezawa, H. (1964) J. Antibotics, 17A : 96 . 